\title{
Strategic or Non-Strategic: The Role of Financial Benefit in Bankruptcy
}

By

\author{
Shuoxun Zhang, Tarun Sabarwal, and Li Gan ${ }^{1}$
}

This version: July 16, 2014

\begin{abstract}
A partial test for strategic behavior in bankruptcy filing may be formulated by testing whether consumers manipulate their debt and filing decision jointly, or not: that is, testing for endogeneity of financial benefit and the bankruptcy filing decision. Using joint maximum likelihood estimation of an extended discrete choice model, test results are consistent with non-strategic filing: financial benefit is exogenous to the filing decision. This result is confirmed in two different datasets (PSID and SCF). This result is consistent with an ex ante low net gain from a bankruptcy filing; a type of "rational inattention" to rare events such as bankruptcy.
\end{abstract}

Keywords: Consumer bankruptcy, personal bankruptcy, adverse events, strategic filing JEL Classification: D12, D14

\footnotetext{
${ }^{1}$ Zhang: Research Institute of Economics and Management, Southwestern University of Finance and Economics, Chengdu, China, shuoxun@swufe.edu.cn Sabarwal: Department of Economics, University of Kansas, sabarwal@ku.edu Gan: Department of Economics, Texas A\&M University, and NBER, gan@econmail.tamu.edu.
} 


\section{Introduction}

Personal bankruptcy rates have increased at an annual rate of 3.9 percent since 1990, from about 718 thousand (non-business) bankruptcies in 1990 to about 1.5 million in 2010. Partly as a response to this increase, the Congress passed the Bankruptcy Abuse Prevention and Consumer Protection Act of 2005, the largest overhaul of bankruptcy laws since 1980. Although recent data is too sparse to determine the longer-term effectiveness of the law, we know that there was a spike in bankruptcy filings in 2005 (just before the law took effect on October 17, 2005) and a corresponding decline in 2006. Since then, bankruptcies have continued to rise, reaching a level of about 1.5 million in 2010, the same level as in 2004. (The bankruptcy rate has also begun to creep up to the earlier levels.) One of the major purposes of the new bankruptcy law was to cut down on abusive or fraudulent uses of the bankruptcy system, or in our words, strategic use of the law. Therefore, it is important to understand the motivations of consumers who file for bankruptcy, what constitutes "strategic" use of bankruptcy law, and how widespread is its incidence.

In the literature, there is no clear definition of what constitutes a strategic bankruptcy filing. We shall consider strategic behavior to be a conscious decision to benefit from bankruptcy law. To make this tractable, consider a simple two-period model of decisionmaking. In the first period, consumers receive a noisy signal of experiencing a financial shock in the second period. Based on this signal, consumers may update their probability of an adverse shock and choose their debt level. In the second period, the shock is realized and consumers decide whether to file for bankruptcy or not. A strategic consumer is one who in the first period, chooses her debt level after conditioning on the signal; that is, a strategic consumer takes on debt after accounting for the chance of filing for bankruptcy. In other words, a strategic consumer is one who is fully rational, and takes decisions to maximize her benefit. A non-strategic consumer is one who 
chooses debt level without conditioning on the signal; he plans to repay his debt in the absence of adverse events. Such a consumer is myopic, and may be exhibiting rational inattention (as described below).

Consistent with this view, we may distinguish between strategic and non-strategic behavior by testing whether consumers make their debt and filing decision jointly, or not. Strategic behavior is consistent with a joint decision, non-strategic behavior is not. In terms of empirical strategy, this is implemented by testing whether financial benefit is endogenous to the filing decision or not.

Our test is different from the one in Fay, Hurst, and White (2002) (henceforth, FHW). In that approach, a positive relationship between filing for bankruptcy and financial benefit from filing, ceteris paribus, is taken as evidence of strategic behavior; and a positive relationship between filing for bankruptcy and adverse events (such as divorce, health shocks, employment shocks, and so on) is taken as evidence of non-strategic behavior. Using data from the Panel Study of Income Dynamics (PSID), FHW show that financial benefit is positively and significantly related to the filing decision, and after controlling for financial benefit, adverse events variables do not affect the bankruptcy decision (except for a marginally significant positive effect of divorce). ${ }^{2}$

This simple empirical relationship between bankruptcy filing and financial benefit does not consider more realistic relationships between financial benefit, adverse events, and strategic behavior. For example, financial benefit from filing may go up due to adverse events, regardless of whether a consumer is trying to abuse bankruptcy law or not. That is, financial benefit goes up when a consumer consciously increases unsecured debts before filing, consistent with strategic behavior; and it also goes up when she uses

\footnotetext{
${ }^{2}$ Using Survey of Consumer Finances (SCF) data, we document a similar relationship for financial benefit, but a strongly significant and positive effect of divorce. With the FHW interpretation, the PSID data provide some support for strategic behavior while the SCF data provide some support for both strategic and the non-strategic behavior.
} 
unsecured debt (e.g. a credit card) to pay for expenses due to adverse events, consistent with non-strategic behavior. Moreover, a non-strategic consumer may appear strategic to the analyst, if he rolls over debt as long as there is hope of repaying it. This leads to greater measured financial benefit before filing, despite no intent to abuse bankruptcy law. Indeed, equilibrium models of default typically include such features. ${ }^{3}$

In other words, financial benefit is affected by both strategic and non-strategic behavior, and a positive coefficient on financial benefit alone is insufficient to distinguish between the two behaviors. ${ }^{4}$

Our test partially disentangles the role of financial benefit, adverse events, and strategic behavior: it allows for a positive relationship between bankruptcy filing and financial benefit for both strategic and non-strategic consumers and still may distinguish between the two. This test cannot distinguish between strategic consumers and nonstrategic consumers who may appear strategic due to a non-strategic run-up of debt before filing.

Consequently, if the test result shows that financial benefit is endogenous to the filing decision, that result can be consistent with both strategic and non-strategic behavior. If the test result shows that financial benefit is exogenous to the filing decision, the result supports non-strategic filing behavior (and shows that the incidence of both strategic

\footnotetext{
${ }^{3}$ The literature on consumer bankruptcy is very large. A partial list includes the following. Stanley and Girth (1971) and Eaton and Gersovitz (1981) present early work in this area. Additional work includes Sullivan, Warren, and Westbrook (1989, 1994, and 2000), White (1987, 1998), Ausubel $(1991,1997)$, Domowitz and Sartain (1999), Gross and Souleles (2002), Fay, Hurst, and White (2002), Fan and White (2003), Han and Li (2004), and Livshits, Macgee, and Tertilt (2007, 2010). Athreya (2005) provides a survey of equilibrium models of default. Additional theoretical contributions include Zame (1993), Modica, Rustichini, and Tallon (1999), Araujo and Pascoa (2002), Sabarwal (2003), Dubey, Geanakoplos, and Shubik (2005), Geanakoplos and Zame (2007), and Hoelle (2009), among others.

${ }^{4}$ This point may be made more generally: we show that in the standard random utility model underlying the binary choice of filing and not filing, the coefficient on unsecured debt (and hence, on financial benefit from filing) is positive, regardless of how debt is accumulated.
} 
filings and non-strategic filings that may appear strategic is statistically insignificant in the data).

We propose a model in which financial benefit and the filing decision are jointly determined, estimate it using joint maximum likelihood, and test for endogeneity of financial benefit and the filing decision. The discussion provides a set of natural instrumental variables, the adverse events.

Using two different datasets (PSID and SCF), ${ }^{5}$ the test results are consistent with nonstrategic behavior, in contrast to FHW. With both datasets, financial benefit is exogenous to the filing decision. Moreover, with both datasets, the coefficient on financial benefit is strongly significantly positive.

Our finding is consistent with "rational inattention" to rare events such as bankruptcy; that is, ex ante, the benefit from a bankruptcy filing is very low relative to costs, leaving little incentive for consumers to actively "plan" to file for bankruptcy. For example, as reported in FHW, for families that can gain from a bankruptcy filing, the mean benefit from filing is $\$ 7,813$, and the probability of filing is 0.003017 , for an ex-ante filing benefit of about $\$ 25$. This is less than the cost of a planning session with a bankruptcy lawyer, or the resources expended to purchase and plan with a book on how to file for bankruptcy. Note that planning for a strategic bankruptcy would have to be done early enough, because legal restrictions disallow wealth re-allocations designed to gain from bankruptcy, especially if these are within about six months prior to a bankruptcy filing.

The paper proceeds as follows. Section 2 describes the basic theory and a theoretical result on positive correlation between financial benefit and filing probability. Section 3 presents the econometric specifications, and results, and section 4 concludes.

\footnotetext{
${ }^{5}$ Although both PSID and SCF are among the best publicly available datasets of their kind, they have wellknown limitations for bankruptcy research. Using two datasets provides some robustness to these results, but better bankruptcy data would help to arrive at stronger conclusions.
} 


\section{Basic theory and Positive Correlation between Financial Benefit and Filing Probability}

Bankruptcy filers typically have a choice between filing for Chapter 7 or Chapter 13 bankruptcy. ${ }^{6}$ A Chapter 7 bankruptcy process liquidates a filer's estate, and net of exemptions, makes payments to creditors based on law. This is sometimes termed a straight bankruptcy. In a Chapter 13 filing, a filer typically keeps his assets, proposes a plan of repayment, and on plan completion, gets discharge from remaining debts. Historically, about 70 percent of bankruptcies are Chapter 7, and most of the remainder are Chapter 13. Moreover, a filing under Chapter 13 may be moved to Chapter 7, if the Chapter 13 repayment plan is not completed successfully. In practice, this can happen in a significant proportion of Chapter 13 filings. $^{7}$ Therefore, most research models Chapter 7 bankruptcy filing. We follow the same approach. ${ }^{8}$

Consider a simple two-period model of decision-making. Prior to the first period, consumers receive a noisy signal of experiencing a financial shock. The shock may be viewed as an adverse event: job loss, health problem, divorce, and so on. Based on this signal, consumers may update their probability of an adverse shock. In the first period, they choose their debt level. Then the shock is realized and in the second period, consumers decide whether to file for bankruptcy or not.

\footnotetext{
${ }^{6}$ Before BAPCPA, consumers had more freedom in choosing the chapter in which to file. After BAPCPA, choice is restricted by a "means" test $(\S 707(b)(2))$. Given the high rate of failures of Chapter 13 plans, it is as yet unclear how many consumers required to file under Chapter 13 eventually end up with a discharge under Chapter 7. The analysis here and the dataset used are for filings before BAPCPA.

${ }^{7}$ Sullivan, Warren, and Westbrook (2000, p. 14) estimate this to be about two-thirds of Chapter 13 filings.

${ }^{8}$ A Chapter 13 filing may be viewed as a reduced form Chapter 7 filing, where debt recovery is the total amount repaid over the course of the proposed plan. We do not force such an interpretation.
} 
As shown in figure 1, a strategic consumer is one who in the first period, chooses her debt level after conditioning on the signal. A strategic consumer understands that based on an adverse event there is some chance of a bankruptcy filing, in which case some debt is forgiven. She plans accordingly, and chooses a debt level to achieve the highest benefit available under law. In other words, a strategic consumer is one who is fully rational, and takes decisions to maximize her benefit.

Figure 1: Timeline

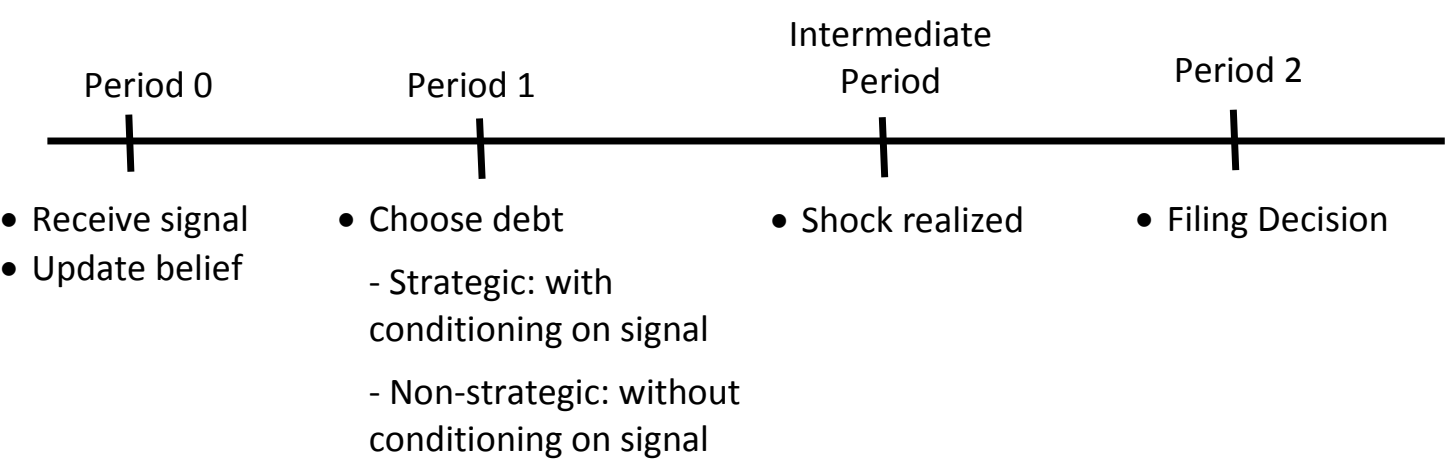

A non-strategic consumer is one who chooses debt level without conditioning on the signal. Intuitively, a non-strategic consumer understands that based on an adverse event there is some chance of a bankruptcy filing, but does not plan to additionally benefit from a filing. He plans to repay his debt in the absence of adverse events. Such a consumer is myopic, but that may not necessarily imply he is irrational.

This situation can be formalized using a simple two-period model of expected utility maximization. In the first period, there is one decision node. In the second period, depending on a shock (that we may assume occurs at an intermediate stage) one of two states may occur: a good state, indexed $g$, and an adverse events state, indexed $a$. State-contingent consumption is indexed $c_{0}, c_{g}, c_{\alpha}$. A consumer's von-NeumannMorgenstern utility index is given by $u(c)$, with standard assumptions $\left(u^{\prime}>0, u^{n}<0, \lim _{c \rightarrow 0} u^{\prime}(c)=\infty, \lim _{c \rightarrow \infty} u^{\prime}(c)=\infty\right)$. Expected utility is given by 
$u\left(c_{0}\right)+\delta\left[\pi_{g} u\left(c_{g}\right)+\pi_{a} u\left(c_{a}\right)\right]$, where the distribution $\left(\pi_{g}, \pi_{a}\right)$ captures uncertainty in the second stage. Consumer's state-contingent wealth is given by $w_{0}, w_{g}, w_{a}$. For convenience, we assume $0=w_{0}<w_{a}<w_{g}$.

Consumption in first period is financed by debt $d>0$, available at a (risk-adjusted) interest rate $r>0 .{ }^{9}$ For non-trivial solution, we assume debt limit for a consumer is given by $\bar{d}>0$, so that $d$ is constrained to satisfy $d \leq \bar{d}$. Exemptions in bankruptcy are given by $e>0$. A natural assumption in this setting is $w_{a}<e<w_{g}$.

A strategic consumer is fully rational, maximizing $u\left(c_{0}\right)+\delta\left[\pi_{g} u\left(c_{g}\right)+\pi_{a} u\left(c_{a}\right)\right]$ subject to (1) $c_{0}=d,(2) c_{g}=\max \left\{w_{g}-(1+r) d, \min \left\{w_{g}, e\right\}\right\}$, and (3) $c_{a}=\max \left\{w_{a}-(1+r) d, \min \left\{w_{a}, e\right\}\right\}$. Here, $\left(\pi_{g}, \pi_{a}\right)$ is the (updated) belief of the probability of an adverse event, based on the signal received. The minimum operation is a proxy for loss of non-exempt assets in a bankruptcy filing, and the maximum operation corresponds to the bankruptcy decision: file when non-exempt assets are greater than net wealth remaining after debt repayment. The effective decision variable is $d$. Notice that our assumptions imply that in the adverse event state, the consumer files for bankruptcy and consumes $c_{\alpha}=w_{a}$.

A non-strategic consumer does not condition debt decision on the adverse events signal captured by the (updated) distribution $\left(\pi_{g}, \pi_{a}\right)$. Such a consumer may be viewed as taking decision sequentially. In period 1 , the consumer maximizes $u\left(c_{0}\right)+\delta u\left(c_{g}\right)$, subject to (1) $c_{0}=d$ and (2) $c_{g}=w_{g}-(1+r) d$. Effectively, a non-strategic consumer is not planning for a bankruptcy filing and plans to repay his debt in period 2 . If, however, an adverse event occurs in period 2, the consumer re-optimizes to set

\footnotetext{
${ }^{9}$ This is a simple model of individual decision-making, not general equilibrium. We take the risk-adjusted interest rate (price of debt) as given.
} 
$c_{\alpha}=\max \left\{w_{\alpha}-(1+r) d, \min \left\{w_{\alpha}, e\right\}\right\}$. Our assumptions imply that in the adverse events state, consumer files for bankruptcy and consumes $c_{\alpha}=w_{\alpha}$.

By construction, this formulation shows immediately that for a strategic consumer, debt and filing decision are determined jointly, whereas for a non-strategic consumer, this is not the case. ${ }^{10}$ Moreover, a strategic consumer may file for bankruptcy in a good state (in which exemption is low relative to wealth), if debt elimination from bankruptcy can offset the loss of non-exempt assets. A non-strategic consumer does not engage in such behavior.

One way to motivate non-strategic behavior is in terms of rational inattention to rare events. In other words, ex-ante, a non-strategic consumer behaves as if his subjective probability of an adverse event is zero. This might not necessarily be irrational, if we expand the model to include some ex-ante cost of determining the probability of an adverse event and planning for a bankruptcy filing, and the ex-ante benefit from a bankruptcy filing, and then consider a behavioral choice whether a consumer would want to behave strategically or non-strategically. Such an extension is beyond the scope of this paper, but as reported in FHW, for families that can gain from a bankruptcy filing, the mean benefit from filing is $\$ 7,813$, and the probability of filing is 0.003017 , for an ex-ante filing benefit of about $\$ 25$. If a consumer were to plan to gain from a bankruptcy filing, he would include the ex-ante cost of a planning session with a bankruptcy lawyer, or the resources expended to purchase and plan with a book on how to file for bankruptcy; this is typically greater than $\$ 25$. This would have to be done early enough, because legal restrictions disallow wealth re-allocations designed to gain from bankruptcy, especially if these are within about six months prior to a bankruptcy filing.

\footnotetext{
${ }^{10}$ Using standard assumptions, it is easy to show that both problems have an interior solution, and optimal debt for a strategic consumer is (weakly) greater than that for a non-strategic consumer.
} 
An immediate consequence of this model is that for a strategic consumer, financial benefit is endogenous to the filing decision, and for a non-strategic consumer, it is exogenous. This leads us to the empirical test used here.

As mentioned above, this empirical test only partly disentangles the endogeneity, because even for a non-strategic consumer, there might be some debt accumulation after the shock is realized, if the consumer is trying to roll over debt with the hope of repaying it. But a finding of exogeneity favors non-strategic behavior.

In empirical work, filing for bankruptcy is typically modeled as a binary choice model. FHW indicate that a positive and significant relationship between household financial benefit and probability of filing for bankruptcy signals strategic behavior by a consumer. Similarly, Adams, Einav, and Levin (2009) suggest that an increase in probability of default with loan size is consistent with either moral hazard behavior or adverse selection behavior. In the same spirit, we show that financial benefit may affect the probability of filing, regardless of how debt is accumulated.

According to McFadden's Random Utility Maximization model, the probability that a person files for bankruptcy is increasing in the utility difference between filing and not filing. To investigate this difference, let $d$ be unsecured debt and $w$ be assets minus secured debt. For simplicity, the exemptions are normalized to be zero. Financial benefit from filing, given $d$, is $B($ file,$d)=\max (d-w, 0)$, and financial benefit from not filing, given $d$, is $B($ Not,$d)=\max (w-d, 0)$. Notice that $B($ file, $d) \geq B($ Not, $d)$ if and only if $d$ $\geq w$.

Let $u$ denote utility from monetary outcomes. Assume that $u$ is strictly increasing and continuously differentiable. We may write utility from filing, given $d$ as:

$U($ file,$d)=u(B($ file,$d)) ;$ utility from not filing, given $d$ as $U(N o t, d)=u(B($ Not,$d)) ;$ and the difference in these utilities is $\Delta U(d)=U($ file, $d)-U($ Not,$d)$. Therefore, 


$$
\Delta U^{\prime}(d)=u^{\prime}(B(\text { file }, d)) B^{\prime}(\text { file }, d)-u^{\prime}(B(\text { Not }, d)) B^{\prime}(\text { Not }, d)
$$

Consider the following cases. Case $1: d>w$. In this case, $B^{\prime}($ file, $d)=1$ and $B^{\prime}(N o t, d)=0$. Therefore, $\Delta U^{\prime}(d)=u^{\prime}(B(N o t, d))>0$. Case $2: d<w$. In this case, $B^{\prime}($ file,$d)=0$ and $B^{\prime}($ Not,$d)=-1$, whence, $\Delta U^{\prime}(d)=u^{\prime}(B($ Not,$d))>0$. Case 3: $d=w$.

In this case, $\lim _{d \downarrow_{w}} u^{\prime}(B($ file, $d))=u^{\prime}(B($ file,$w))=u^{\prime}(0)>0$, and similarly, $\lim _{d \uparrow w} u^{\prime}(B($ Not,$d))=u^{\prime}(B($ Not,$w))=u^{\prime}(0)>0$. In all cases, we have $\Delta U^{\prime}(d)>0$.

In terms of empirical prediction, this implies that the coefficient on unsecured debt (and consequently, on financial benefit from filing) is positive, regardless of how debt is accumulated. ${ }^{11}$ Therefore, given unsecured debt $d$, a positive relationship between financial benefit from filing and filing for bankruptcy is expected.

\section{Econometric Models and Results}

In this section, we first provide some information on the data and construction of variables. Next, we replicate the FHW's specification using two different datasets. Then we present test results for endogeneity of financial benefit (using joint maximum likelihood estimation) with two different datasets. Finally, we use comparative statistics to predict the bankruptcy filing rates with hypothetical changes in key variables.

\subsection{Data description and variables}

We use two different datasets to check robustness of our results. One is the combined cross-section and time series sample of PSID households over the period 1984-1995; the

\footnotetext{
${ }^{11}$ Notice that all we used here was that $u$ is strictly increasing and continuously differentiable. No additional restriction is imposed on utility.
} 
same dataset is used in FHW. The other is the cross sectional dataset of SCF from 1998. $^{12}$

In 1996, the PSID asked respondents whether they had ever filed for bankruptcy and if so, in which year. This information, combined with other household characteristics forms the basis of our first dataset. The PSID data are generally of high quality, but they have some limitations for a study of this kind. In particular, wealth is only measured at 5-year intervals, and it contains less detail on some aspects of use in this study. Moreover, as documented in FHW, there are only 254 bankruptcy filings over the period 1984-1995, and bankruptcy filings in the PSID are only about one-half of the national filing rate.

SCF, in contrast, has 55 bankruptcy filings in 1997, or about 1.28 percent of households, comparable to the 1997 national bankruptcy filing rate of 1.16 percent. The SCF is crosssectional only, so we lose the time-series aspect in this case; but there is some information for the year prior to the survey, and on future expectations.

SCF also provides better wealth data, which reports 1997 wealth information and 1997 bankruptcy filings. (The SCF survey was conducted in 1998, between June and December.) ${ }^{13}$

We do not distinguish Chapter 7 and Chapter 13 filings in this paper (although consumers are able to make choices), because the financial benefit from filing under Chapter 13 is closely related to that from filing under Chapter 7. It usually takes between four and six months for a Chapter 7 filing procedure, but between 36 and 60 months for a typical Chapter 13 case. The 1998 SCF does not provide information on

\footnotetext{
${ }^{12} \mathrm{SCF}$ asks the respondents about their bankruptcy history, but the region/state in which they stay is not revealed to the public after 1998. In order to match the two datasets, we choose the data of the most recent year.

${ }^{13}$ See Kennickell et. al (1998).
} 
chapter choice. Financial benefit from filing is the key variable in this paper. As in FHW, it is calculated as follows:

$$
B_{i, t}=\max \left\{D_{i, t}-\max \left(W_{i, t}-E_{i, t}, 0\right), 0\right\},
$$

where $B_{i, t}$ is the financial benefit from filing for household $i$ in period $t, D_{i, t}$ is the unsecured debt discharged in bankruptcy for household $i$ in period $t, W_{i t}$ is the value of wealth for household $i$ in period $t$, and $E_{i, t}$ is value of exemptions under law for household $i$ in period $t$, in the household's state of residence. In this formula, $\max \left(W_{i, t}-E_{i, t}, 0\right)$ calculates the nonexempt assets that a filer loses in bankruptcy. It is a measure of financial cost of filing for bankruptcy. The variable $D_{i, t}$ is the part that will be discharged in bankruptcy, thus is a measure of benefit of filing. As not filing dominates filing when $D_{i, t}-\max \left(W_{i, t}-E_{i, t}, 0\right)$ is negative, the financial benefit from filing is truncated at 0 to yield the above formula.

Notice that this calculation does not include the full economic cost of a bankruptcy filing. For example, a more complete measure of the economic cost of filing would include future and dynamic costs of a bankruptcy filing as well, such as loss of future stream of profits from liquidated assets, or effects on future credit-worthiness, which determines future access to debt markets and the price of debt. A more complete accounting of the cost of bankruptcy would include such costs and also out-of-pocket filing costs. Reliable data on these measures is unavailable, and including a reduced form constant would not change the qualitative results. This is a limitation of our approach, as also that of FHW.

To calculate financial benefit in the PSID, we use the same dataset and calculation as FHW. In the PSID, housing equity is reported every year, but non-housing wealth is reported only in the 5-yearly wealth supplements from 1984, 1989, and 1994. These data are used to construct unsecured debt, $D_{i, t}$, that will be discharged in bankruptcy. 
Wealth includes current year housing equity (reported every year) and the value of the most recent prior report on non-housing wealth. ${ }^{14} W_{i, t}$, is the wealth net of secured debts (like mortgages and car loans). Exemption, $E_{i, t}$, is the exemption in the state of residence of household $i$ in period $t$.

For the SCF, variables are constructed similarly. The variable $D_{i, t}$ measures unsecured debt that will be discharged in bankruptcy. Unsecured debts include both credit card debt and installment loans. ${ }^{15}$ Wealth $W_{i, t}$, is total assets net of the secured debt. Total assets include all financial assets and non-financial assets. ${ }^{16}$ For exemption, $E_{i, t}$, we make the following adjustments.

The SCF provides only region codes; state codes are not released in public data. To get a relative weight for each state in a region, we use Regional Economic Information System (REIS) from the Bureau of Economic Analysis. These state weights are based on the population of a state relative to the region in which it is included. These weights are used to compute the composite exemption level of a region. Moreover, using Elias, Renauer, and Leonard (1999), we determine each state's exemption levels for 1998 for homestead equity in owner-occupied homes, equity in vehicles, personal property, and

\footnotetext{
${ }^{14}$ Data on unsecured debt and non-housing wealth is subject to measurement error and therefore financial benefit is subject to measurement error, but as reported in FHW, this does not significantly affect the results.

${ }^{15}$ Credit card debt includes not only the traditional Visa/Mastercard/Discover/Optima cards, but also revolving debts at stores, including store cards, gasoline cards, airline cards and diner club cards. Installment loans refer to those for purposes other than purchasing houses or real estates.

${ }^{16}$ Financial assets are the sum of all types of transactions accounts(checking accounts, saving accounts, money market accounts and call accounts), certificates of deposits, total directly-held mutual funds, bonds, stocks, total quasi-liquid(sum of IRAs, thrift accounts, and future pensions), saving bonds, cash value of whole life insurance, other managed assets (trusts, annuities and managed investment accounts in which household has equity interest), other financial assets: includes loans from the household to someone else, future proceeds, royalties, futures, non-public stock, deferred compensation, oil/gas/mineral investments, and cash not elsewhere classified.
} 
wildcard exemptions. We adjust for state level variables to the extent we can. For example, if a state doubles exemptions for married households, we do the same. For the fifteen states allowing residents to choose between state or federal exemptions, we take the larger of the exemptions. For households in states with an unlimited homestead exemption, we take the homestead exemption to be the average of home values in the entire sample. The exemption variable, $E_{i, t}$, is the sum of these exemptions. ${ }^{17}$ To make the two datasets consistent with each other, we include a vector of demographic variables which may be related to households' filing decisions, such as age of household head, years of education of the head, family size, whether head owns their home and whether head owns business. For SCF data, we include only region dummies rather than macro information to capture local fixed effects, due to lack of information regarding state of residency.

For adverse events variables, we include whether the head was ever unemployed during the prior twelve months (labeled "unemployed"), total weeks of unemployment during the prior twelve months (labeled "period of unemployment"), ${ }^{18}$ its squared term, whether the head is recently divorced (labeled "divorce"), ${ }^{19}$ and whether the head's (self-reported) health condition is poor (labeled "health"). ${ }^{20}$

In table 1, we present financial benefit and unsecured debt between filers and non-filers for both PSID and SCF. Similar patterns emerge. In PSID, the mean log(financial benefit)

\footnotetext{
${ }^{17}$ The exemption levels calculated using PSID and using SCF have different advantages and flaws, and thus subject to measurement errors, but it does not significantly affect the results.

${ }^{18}$ We uniformly recode the variable to be 52 if the spell of unemployment is more than one year.

${ }^{19}$ The reported results in Table 4 and 6 are using the dummy variable for divorce during years of 19961998 , but we have tried dummy variables for divorce of each year, which do not change the significance of the result/coefficient.

${ }^{20}$ We also tried the dummy for either the head or the partner was in poor health status. The results remain robust.
} 
for filers is more than twice as much than those non-filers. In SCF, filers have more than three times as much mean $\log$ (financial benefit) than non-filers. In both SCF and PSID, the mean $\log$ (unsecured debt) for filers is greater than that of non-filers.

As in FHW, our debt calculation is for the period of filing, and the adverse events variables are for the prior period. This is consistent with our model (with adverse events realized before the bankruptcy decision).

There is the issue that in the data, it is possible that debt (and therefore, financial benefit) changes after an adverse event occurs and before a bankruptcy filing. We can consider two cases.

First, an adverse event (which here is assumed to occur with an exogenous probability) itself leads to an increase in debt. This is captured in the model in a reduced form by a reduction in state-contingent wealth, and empirically in the financial benefit calculation.

Second, a consumer might take some actions that change debt just before filing. For example, a strategic consumer could try and consciously increase unsecured debts just before filing in order to increase benefit from filing. As mentioned above, there are legal restrictions for such moves and creditors are likely to have these enforced strictly. On the other hand, debt may go up when a non-strategic consumer rolls over debt in the hope of repaying it. As mentioned earlier, our test cannot distinguish between strategic consumers and non-strategic consumers who may appear strategic due to a nonstrategic run-up of debt before filing.

Consequently, if the test result shows that financial benefit is endogenous to the filing decision, that result can be consistent with both strategic and non-strategic behavior. If the test result shows that financial benefit is exogenous to the filing decision, the result supports non-strategic filing behavior (and shows that the incidence of both strategic 
filings and non-strategic filings that may appear strategic is statistically insignificant in the data).

\subsection{Simple Probit model}

Let's first consider a simple Probit regression, similar to FHW's specification.

file $=1(\gamma B+X \beta+\alpha A+u>0)$

This specification explores strategic and non-strategic behavior by running the Probit regression of whether households file for bankruptcy (file) as a function of their potential financial benefit, $B$, from filing, their personal and state characteristics $X$, and the adverse events they encountered in the previous year, $A$.

As described above, one test of strategic behavior focuses on the significance of the coefficients on financial benefit and on adverse events, as in FHW. If strategic behavior hypothesis is true, the coefficients of financial benefit should be positive and significant while the adverse event variables should not be significant. If non-strategic behavior hypothesis is true, then adverse event variables should be positive and significant while the coefficient of financial benefit should be insignificant.

Table 2 illustrates this simple specification with PSID data and SCF data. ${ }^{21}$ (For ease of comparison, we keep the other variables same as those in FHW.) As shown in table 2,22 using PSID data, the coefficients on the variables are comparable to those reported in FHW. In particular, financial benefit affects the filing decision positively and highly significantly, and its squared term is highly significant. And, among statistically

\footnotetext{
${ }^{21}$ For all estimates, * indicates significance at 90 percent, $* *$ at 95 percent, and $* * *$ at 99 percent.

${ }^{22}$ The pseudo R-square for the four columns of Table 2 are 0.1378, 0.1320, 0.1377, and 0.1524, respectively. The first two columns use the PSID family weights. Standard errors (in PSID) are corrected using the Huber/White procedure, which allows error terms for the same household to be correlated over time. We apply this procedure to table 3 and table 5, too.
} 
significant adverse events, divorce is positive but only marginally significant. When using SCF data, financial benefit continues to be positive and highly significant, but its squared term is marginally significant. The coefficient on divorce remains positive, but is highly significant.

Thus, using the simple Probit model, the PSID dataset provides support for strategic behavior, as in FHW, while the SCF dataset provides support for both strategic and nonstrategic behavior, providing an indication of alternative behavior in the data.

\subsection{Model with Joint Determination of Financial Benefit and Filing Decision}

As mentioned in the introduction, a simple empirical relationship between filing for bankruptcy and financial benefit from filing conflates more realistic relationships between financial benefit, adverse events, and strategic behavior. To disentangle some of these relationships, we propose to test the endogeneity of financial benefit in a more general model in which financial benefit and the bankruptcy decision are allowed to be determined jointly. It is reasonable to believe that consumers' attitude toward debt (and thus financial benefit), which is unobserved, determines both how they accumulate debt and whether or not they file for bankruptcy.

As discussed above, non-strategic households would respond to income shocks, but not respond additionally to financial benefit upon filing. Strategic households could manipulate their debts so that their financial benefits from bankruptcy are maximized, in other words, their financial benefits and bankruptcy decision are simultaneously determined. To test these two hypotheses is equivalent to testing whether financial benefit is endogeneous or not.

Hence, we have the basic empirical model as follows:

$$
\text { file }^{*}=X \beta+\gamma \ln (B+1)+u, \quad\left\{\begin{array}{lll}
\text { file }=1 & \text { if } & \text { file } \\
\text { file }=0 & \text { if } & \text { file } \\
\text { file } &
\end{array}\right.
$$




$$
\ln \left(B^{*}+1\right)=X \delta+\mu A+v,\left\{\begin{array}{lll}
B=B^{*} & \text { if } & B^{*} \geq 0 \\
B=0 & \text { if } & B^{*}<0
\end{array}\right.
$$

The key difference between this model and FHW's specification is the role of the set of adverse events, $A$. Here, $A$ no longer directly affects a person's bankruptcy decision. Instead, it serves as the set of instrumental variables that directly affects the financial benefits, $B$, in (4). Since adverse events are exogenous to a household's bankruptcy decision, they act more as a negative shock to a household's income/wealth.

Another minor difference between these two models is that the logarithm of financial benefit is used here while FHW use the level of financial benefits. As $B$ depends on the wealth level, it is most likely to exhibit a log-normal distribution, although censored at zero. With a logarithm transformation, we will assume that $v$ is normally distributed.

Notice that endogeneity of $\ln (B+1)$ is equivalent to whether the error terms $u$ and $v$ are correlated. Let $\operatorname{Var}(u)=1, \operatorname{Var}(v)=\sigma_{v}^{2}$, and assume the relationship between $u$ and $v$ as follows:

$$
u=\theta v+\varepsilon
$$

where $\operatorname{Cov}(v, \varepsilon)=0$, and $\operatorname{Var}(\varepsilon)=1-\theta^{2} \sigma_{v}^{2}$. In this version, the exogeneity of $\ln (B+1)$ is equivalent to the hypothesis that the parameter $\theta=0$. The probability a household files when financial benefit is zero is given by

$$
\operatorname{Pr}(\text { file }=1, \ln (B+1)=0)=\int_{-\infty}^{-X \delta-\mu A} \Phi\left(\frac{X \beta+\theta v}{\sqrt{1-\theta^{2} \sigma_{v}^{2}}}\right) \frac{1}{\sigma_{v}} \phi\left(\frac{v}{\sigma_{v}}\right) d v
$$

and accordingly, the probability it does not file when financial benefit is zero is given by 


$$
\operatorname{Pr}(\text { file }=0, \ln (B+1)=0)=\int_{-\infty}^{-X \delta-\mu A} \Phi\left(-\frac{X \beta+\theta v}{\sqrt{1-\theta^{2} \sigma_{v}^{2}}}\right) \frac{1}{\sigma_{v}} \phi\left(\frac{v}{\sigma_{v}}\right) d v
$$

Similarly,

$$
\begin{aligned}
& \operatorname{Pr}(\text { file }=1, \ln (B+1)) \\
& =\Phi\left(\frac{X \beta+\gamma \ln (B+1)+\theta(\ln (B+1)-X \delta-\mu A)}{\sqrt{1-\theta^{2} \sigma_{v}^{2}}}\right) \frac{1}{\sigma_{v}} \phi\left(\frac{\ln (B+1)-X \delta-\mu A}{\sigma_{v}}\right), \text { and }
\end{aligned}
$$

$\operatorname{Pr}($ file $=0, \ln (B+1))$

$$
=\left[1-\Phi\left(\frac{X \beta+\gamma \ln (f b+1)+\theta(\ln (B+1)-X \delta-\mu A)}{\sqrt{1-\theta^{2} \sigma_{v}^{2}}}\right)\right] \frac{1}{\sigma_{v}} \phi\left(\frac{\ln (B+1)-X \delta-\mu A}{\sigma_{v}}\right) .
$$

The log-likelihood function over the sample is given by

$$
\begin{aligned}
l= & \sum_{\text {file }=0, \ln (B+1)>0} \ln (\operatorname{Pr}(\text { file }=0, \ln (B+1)>0))+\sum_{\text {file }=1, \ln (B+1)>0} \ln (\operatorname{Pr}(\text { file }=1, \ln (B+1)>0)) \\
& +\sum_{\text {file }=0, \ln (B+1)=0} \ln (\operatorname{Pr}(\text { file }=0, \ln (B+1)=0))+\sum_{\text {file }=1, \ln (B+1)=0} \ln (\operatorname{Pr}(\text { file }=1, \ln (B+1)=0))
\end{aligned}
$$

Estimation results are presented in tables 3 and $4 .{ }^{23}$ We find that using either PSID data (table 3), or SCF data (table 4), the estimated parameter $\theta$ is not statistically different from zero, consistent with non-strategic behavior.

At the same time, log financial benefit has a positive and highly significant effect on the decision to file for bankruptcy in both datasets.

Both datasets confirm the view that adverse events may affect financial benefit. Results using PSID data are presented in Table 3 and those with SCF data in Table $4 .{ }^{24}$ Both

\footnotetext{
${ }^{23}$ We apply a log transformation to financial benefit, because this variable exhibits a distribution that is similar to log-normal but is left-censored at zero. In particular, we use log(financial benefit $+\$ 1$ ). This is to capture the characteristics of censored data at zero. The transformed variable is also left-censored at zero. The result is also robust if the actual value of financial benefit is adopted.
} 
show similar results, with some differences in terms of statistical significance. Intuitively, health problems would lead to a larger amount of debt and thus a potentially higher financial benefit (highly significant in PSID data, not in SCF). In the absence of divorce, there is a greater chance of repaying higher levels of debt (due to joint earnings), leading to lower probability of filing. Or there may be lower levels of debts, due to greater production of services at home (in case one spouse is not working), leading to lower financial benefit from filing. ${ }^{25}$ Conversely, conditional on divorce, financial benefit may be higher (highly significant in SCF data, not in PSID). Moreover, greater financial benefit may also be due to more joint (and individual) debts being discharged to give both partners a fresh start after divorce. Transitioning into unemployment typically lowers access to debt markets, lowering financial benefit from filing (highly significant in PSID, not in SCF). Conditional on being unemployed, an increase in duration of unemployment is more likely to imply utilizing existing debt lines more completely, or increases in debts outstanding due to non-servicing of debt, both increasing financial benefit. This increase may be tempered by more stringent conditions from creditors, leading to an increasing and concave impact on financial benefit (highly significant in PSID data, marginally significant in SCF).

It is possible that not all adverse events have the same impact on filing behavior. For example, a health shock may be less predictable than divorce, and may have a different

\footnotetext{
${ }^{24}$ Since there is no available weak-IV test or Sargan test for the joint determination model, we run the regression with two-stage-least-square to show the related statistics. For PSID, the F-statistic is 18.34, which is greater than the critical value of 10 , by rule of thumb. This rejects the null hypothesis that the instruments are weak. The Sargan score is 5.898, with p-value of 0.21 . So the over-identifying restriction is valid. For SCF, the Anderson-Rubin (AR) statistic (chi-square=22.8), Kleibergen-Moreira Lagrange multiplier (LM) test (chi-square=20.29), the conditional likelihood-ratio (CLR) test (statistic=21.39) all pass the $5 \%$ significance, which rejects the null. The Sargan score is 6.53 , which is 0.16 as of $p$-value. So we do not reject the null hypothesis and the over-identifying restriction is valid.

${ }^{25}$ According to Traczynski (2011), marriage is another kind of individual insurance against adverse shocks through income sharing between partners; when the exemption level is high enough, people will choose to file for bankruptcy instead of using marriage as their income protection.
} 
impact on filing behavior. Therefore, in principle, different adverse events could lead to differing strategic behavior depending on type of adverse event. For robustness, we run the joint determination model with different combinations of adverse events. The main results are unchanged, as shown in Tables 5 and 6.

\subsection{Interpretation}

Tables 7 and 8 show how hypothetical changes in key variables affect financial benefit from filing and probability of filing. Table 7 shows information for the joint determination model using PSID data, whereas Table 8 shows the same information using SCF data.

Suppose financial benefit from filing increases by $\$ 1,000$ for each household..$^{26}$ In this case, the average filing probability is predicted to increase by 0.216 percentage points (PSID data, Table 7) and by 0.56 percentage points (SCF data, Table 8). Given that filing probability is 0.3017 percent (PSID data) and 1.28 percent (SCF data), an increase in financial benefit of $\$ 1,000$ predicts that bankruptcy filing rates would increase by 71.6 percent per year (using PSID data), and by 43.8 percent (using SCF data). Thus, consistent with the basic theory outlined above, even with non-strategic behavior, financial benefit can have a large effect on bankruptcy filings. ${ }^{27}$

We also present predictions for changes in some household characteristics, such as age of head of household, education level, family size, and home ownership.

\footnotetext{
${ }^{26}$ If negative, set the value to be zero.

${ }^{27}$ Notice that the PSID sample has an average financial benefit of $\$ 1411$ (Table 1 ), and a $\$ 1,000$ change is about 70 percent of this number. For the SCF a $\$ 1,000$ change is about a 25 percent increase from the mean of $\$ 3,991$.
} 
If age of head of the average household increases by 10 years, using equation (4), we see that log financial benefit would decrease, on average, by 0.0433 (PSID data) and by 0.0102 (SCF), which would lead to 18.0 percent (PSID) and 4.7 percent (SCF) reduction in annual bankruptcy filing rate.

If head of the average household receives one more year of education, the predicted change in financial benefit is -0.001 (PSID) and -0.1041 (SCF). Bankruptcy filing rates would decrease by 4.7 percent (PSID) and 6.25 percent (SCF).

If the average household adds one member, bankruptcy filing rate increases by 6.0 percent (PSID) and 7.8 (SCF) percent.

Home ownership has different effect in the two samples. If every household turns from having no home to having at least one home, the bankruptcy filing rate using PSID data is predicted to decrease by 24 percent (PSID) while the filing rate using SCF data is predicted to drop only 0.3 percent. This might be due to the fact that SCF does not release state information, and we might under-estimate the homestead exemption if the state does not set a cap on homestead exemption.

Tables 7 and 8 present predictions based on changes in adverse event variables as well, especially if adverse events did not occur. Broadly, except for unemployment, absence of adverse events is predicted to decrease bankruptcy rates, as expected.

If head of an average household turned from being unemployed to having a job, financial benefits are predicted to be higher on average, increasing predicted filing rates by 1.3 percent (PSID) and 3.5 percent (SCF). Given that a head of household is unemployed, if spell of unemployment is 1 week shorter, then financial benefits as well as the bankruptcy filing rate is predicted to decrease by 0.23 percent (PSID) and 0.94 percent (SCF). 
If the average household head turned from having health problem to not having health problem, both predicted financial benefits and predicted bankruptcy filing rates would decrease. The reduction in average bankruptcy rate is 3.7 percent (PSID) and 3.6 percent (SCF), respectively.

Finally,' suppose divorce did not occur, probability of bankruptcy filing is predicted to decrease by 0.5 percent (PSID) and 34.4 percent (SCF).

\section{Conclusion}

Understanding the motivations of consumers to file for bankruptcy is central to the design of appropriate policies to manage the number of filings. For example, if consumers typically file strategically, and it is determined that filings are too high, then policies to reduce filings could include, among others, those that tighten access to bankruptcy courts, or make bankruptcy more expensive, perhaps by restricting access to particular types of bankruptcy provisions, lowering exemptions, diverting more debtors to longer repayment plans, lengthening minimum time between repeat filings, or requiring debt management programs outside of bankruptcy. On the other hand, if consumers typically file non-strategically, then policies to reduce bankruptcy filings could include, among others, those that minimize the impact of adverse events, or increase financial literacy for planning for such events.

This paper proposes a test to detect strategic or non-strategic behavior in bankruptcy filings. The test is based on endogeneity or exogeneity of financial benefit and the bankruptcy decision. The proposed test is more realistic than a simple estimation of the sign of the coefficient on financial benefit and on adverse shocks. The test is partial in that it cannot distinguish between strategic filing and a filing that appears to be strategic due to non-strategic reasons. Nevertheless, test results are consistent with 
non-strategic filing behavior, and rule out significant strategic behavior. The same results hold in two different datasets.

The models used in this paper are simplified and by no means capture all relevant aspects of the bankruptcy decision. Issues related to choosing a particular period to file for bankruptcy, or to repeat interactions with credit markets, or to choice of bankruptcy chapter, or to role of legal advertising, or to effects on supply of credit, or to effects on work incentives, and so on are not considered here. (Some of these are the subject of other papers, listed above.) It is possible to consider some of these issues here in a reduced form by including parameters for expected gains and losses from delaying a decision, or reduced access to credit markets, or utility penalties for default, and then focusing on parameter values which make particular versions of the models more likely to occur, but it is unclear if such additions would have additional applications given the paucity of available data.

The results here can be viewed as providing an indication of some non-strategic behavior in bankruptcy filings, rather than a definitive conclusion in favor of one hypothesis or the other. For example, in addition to research supporting different hypotheses, the reported surge in bankruptcy filings before the deadline of October 17, 2005 for the new bankruptcy law to go into effect suggests that other factors (perhaps informational spillovers emerging from declining social stigma, or lawyer advertising) are important as well. No doubt, additional work may yield additional testable predictions, and additional research would be very welcome. 
Table 1: Summary Statistics

\begin{tabular}{|c|c|c|c|c|}
\hline \multirow[t]{2}{*}{ Variables } & \multicolumn{2}{|c|}{ PSID data } & \multicolumn{2}{|c|}{ SCF data } \\
\hline & Mean value & $\begin{array}{l}\text { Standard } \\
\text { deviation }\end{array}$ & $\begin{array}{l}\text { Mean } \\
\text { value }\end{array}$ & $\begin{array}{l}\text { Standard } \\
\text { deviation }\end{array}$ \\
\hline Number of bankruptcy filings & \multicolumn{2}{|c|}{254} & \multicolumn{2}{|c|}{55} \\
\hline Financial benefit & $\$ 1,411$ & $\$ 10,523$ & $\$ 3,991$ & $\$ 26,001$ \\
\hline $\log ($ financial benefit +1 ) & 1.64 & 3.24 & 1.94 & 3.69 \\
\hline Those file for bankruptcy & 3.65 & 4.26 & 6.78 & 4.38 \\
\hline Log(unsecured debt+1) & 3.85 & 3.94 & 4.35 & 4.45 \\
\hline Those file for bankruptcy & 5.74 & 3.96 & 5.88 & 3. 96 \\
\hline Debts (if financial benefit $>0$ ) & 9,329 & 31,800 & 9,549 & 38,318 \\
\hline $\begin{array}{l}\text { Nonexempt assets(if financial } \\
\text { benefit }>0 \text { ) }\end{array}$ & 585 & 15,000 & 1,981 & 29,429 \\
\hline Household labor income & $\$ 26,552$ & $\$ 32,672$ & $\$ 114,192$ & $\$ 602,833$ \\
\hline Age of household head & 44.19 & 15.96 & 49.84 & 16.52 \\
\hline Years of education of household head & 12.43 & 5.10 & 13.74 & 2.90 \\
\hline Family size & 2.90 & 1.55 & 2.65 & 1.44 \\
\hline Own home & 0.59 & 0.49 & 0.70 & 0.46 \\
\hline Self employed/own business & 0.11 & 0.31 & 0.25 & 0.44 \\
\hline Head is divorced & 0.03 & 0.18 & 0.036 & 0.186 \\
\hline Head is unemployed & 0.06 & 0.23 & 0.097 & 0.295 \\
\hline Weeks of unemployment of head & 6.76 & 2.01 & 1.82 & 7.90 \\
\hline Head has health problem & 0.07 & 0.26 & 0.04 & 0.19 \\
\hline In(income) & & & 8.17 & 4.76 \\
\hline Total number of observations & \multicolumn{2}{|c|}{64,200} & \multicolumn{2}{|c|}{4,305} \\
\hline
\end{tabular}


Table 2: Simple Probit Model

\begin{tabular}{|c|c|c|c|c|}
\hline & \multicolumn{2}{|c|}{ PSID data } & \multicolumn{2}{|c|}{ SCF data } \\
\hline & $\begin{array}{c}\text { without } \\
\text { adverse event } \\
\text { variables }\end{array}$ & $\begin{array}{l}\text { with adverse } \\
\text { event variables }\end{array}$ & $\begin{array}{c}\text { without } \\
\text { adverse event } \\
\text { variables }\end{array}$ & $\begin{array}{l}\text { with adverse } \\
\text { event variables }\end{array}$ \\
\hline financial benefit & $\begin{array}{c}0.00006 * * * \\
(0.00001)\end{array}$ & $\begin{array}{c}0.00006^{* * *} \\
(0.00001)\end{array}$ & $\begin{array}{c}0.00003^{* * *} \\
(6.9 \mathrm{e}-6)\end{array}$ & $\begin{array}{c}0.00003^{* * *} \\
(7 \mathrm{e}-6)\end{array}$ \\
\hline $\begin{array}{l}\text { financial benefit } \\
\text { squared }\end{array}$ & $\begin{array}{c}-1.04 \mathrm{e}-9 * * * \\
(4.04 \mathrm{e}-10)\end{array}$ & $\begin{array}{c}-1.03 e-9 * * * \\
(3.99 e-10)\end{array}$ & $\begin{array}{l}-1.55 e-10^{*} \\
(8.15 e-11)\end{array}$ & $\begin{array}{c}-1.61 \mathrm{e}-10^{* *} \\
(8.2 \mathrm{e}-11)\end{array}$ \\
\hline $\begin{array}{l}\text { lagged bankruptcy } \\
\text { rate }\end{array}$ & $\begin{array}{c}5.95905^{* *} \\
(2.67377)\end{array}$ & $\begin{array}{l}5.62294^{* *} \\
(2.68448)\end{array}$ & & \\
\hline $\begin{array}{l}\text { household labor } \\
\text { income }\end{array}$ & $\begin{array}{c}-4.98 \mathrm{e}-6^{* * *} \\
(1.41 \mathrm{e}-6)\end{array}$ & & $\begin{array}{c}-4.12 \mathrm{e}-6^{* * *} \\
(1.48 \mathrm{e}-6)\end{array}$ & \\
\hline reduction in income & $\begin{array}{c}-2.17 \mathrm{e}-6 * * * \\
(5.92 \mathrm{e}-7)\end{array}$ & & $\begin{array}{c}-2.71 \mathrm{e}-7^{* * *} \\
(7.34 \mathrm{e}-8)\end{array}$ & \\
\hline $\begin{array}{l}\text { age of household } \\
\text { head }\end{array}$ & $\begin{array}{c}0.02917^{* *} \\
(0.0137)\end{array}$ & $\begin{array}{c}0.01846 \\
(0.01306)\end{array}$ & $\begin{array}{c}0.0486 \\
(0.0339)\end{array}$ & $\begin{array}{c}0.0281 \\
(0.0302)\end{array}$ \\
\hline age squared & $\begin{array}{c}-0.00048 * * * \\
(0.00016)\end{array}$ & $\begin{array}{c}-0.00036^{* *} \\
(0.00015)\end{array}$ & $\begin{array}{l}-0.00058 \\
(0.00038)\end{array}$ & $\begin{array}{l}-0.0003 \\
(0.0003)\end{array}$ \\
\hline education & $\begin{array}{c}-0.02981^{* * *} \\
(0.01155)\end{array}$ & $\begin{array}{c}-0.03879 * * * \\
(0.01097)\end{array}$ & $\begin{array}{c}0.0022 \\
(0.0193)\end{array}$ & $\begin{array}{l}-0.0125 \\
(0.0198)\end{array}$ \\
\hline family size & $\begin{array}{l}0.03736^{* *} \\
(0.01673)\end{array}$ & $\begin{array}{l}0.03228^{*} \\
(0.01669)\end{array}$ & $\begin{array}{l}0.0618^{*} \\
(0.0321)\end{array}$ & $\begin{array}{l}0.0631^{*} \\
(0.0334)\end{array}$ \\
\hline own business & $\begin{array}{l}0.04037 \\
(0.0918)\end{array}$ & $\begin{array}{c}0.09489 \\
(0.09147)\end{array}$ & $\begin{array}{l}-0.3162 \\
(0.1949)\end{array}$ & $\begin{array}{l}-0.3321 * \\
(0.1858)\end{array}$ \\
\hline own home & $\begin{array}{l}-0.1371^{*} \\
(0.07437)\end{array}$ & $\begin{array}{c}-0.19982^{* * *} \\
(0.06757)\end{array}$ & $\begin{array}{l}-0.1122 \\
(0.1435)\end{array}$ & $\begin{array}{l}-0.1759 \\
(0.1425)\end{array}$ \\
\hline lawyers per capita & $\begin{array}{c}-0.7776 \\
(0.74456)\end{array}$ & $\begin{array}{l}-0.98042 \\
(0.73636)\end{array}$ & & \\
\hline $\begin{array}{l}\text { county } \\
\text { unemployment rate }\end{array}$ & $\begin{array}{c}0.09337 \\
(0.10457)\end{array}$ & $\begin{array}{c}0.10714 \\
(0.11386)\end{array}$ & & \\
\hline state income growth & $\begin{array}{c}-2.39603^{* *} \\
(1.19746)\end{array}$ & $\begin{array}{l}-2.23304^{*} \\
(1.18386)\end{array}$ & & \\
\hline $\begin{array}{l}\text { state income } \\
\text { deviation }\end{array}$ & $\begin{array}{l}-0.12465 \\
(0.08725)\end{array}$ & $\begin{array}{l}-0.12976 \\
(0.08821)\end{array}$ & & \\
\hline divorce & & $\begin{array}{l}0.23206^{*} \\
(0.13196)\end{array}$ & & $\begin{array}{c}0.7627^{* * *} \\
(0.1765)\end{array}$ \\
\hline $\begin{array}{l}\text { period of } \\
\text { unemployment }\end{array}$ & & $\begin{array}{c}0.0134 \\
(0.02435)\end{array}$ & & $\begin{array}{c}0.0047 \\
(0.0053)\end{array}$ \\
\hline health problem & & $\begin{array}{c}0.09265 \\
(0.11733)\end{array}$ & & $\begin{array}{c}0.0359 \\
(0.2980)\end{array}$ \\
\hline state fixed effects & yes & yes & yes & yes \\
\hline year fixed effects & yes & yes & no & no \\
\hline constant & $\begin{array}{c}-2.3797 * * * \\
(0.71384)\end{array}$ & $\begin{array}{c}-2.23563 * * * \\
(0.75997)\end{array}$ & $\begin{array}{c}-3.5272 * * * \\
(0.8701)\end{array}$ & $\begin{array}{c}-3.2664^{* * *} \\
(0.8059)\end{array}$ \\
\hline
\end{tabular}


Table 3: Joint Determination Model (PSID data)

\begin{tabular}{|c|c|c|}
\hline variables & coefficient & std err \\
\hline Correlation between the two error terms $\theta$ & -0.1402 & 0.1183 \\
\hline \multicolumn{3}{|c|}{ Bankruptcy equation } \\
\hline Log financial benefit & $0.0786 * * *$ & 0.0291 \\
\hline Age & 0.0146 & 0.0114 \\
\hline Age squared & $-0.00026^{* *}$ & .00013 \\
\hline Lagged bankruptcy filing rate & $5.8113^{* *}$ & 2.3557 \\
\hline Education & $-0.0204 * *$ & 0.0083 \\
\hline Family size & 0.0223 & 0.0145 \\
\hline Own business & 0.0528 & 0.0804 \\
\hline Own home & -0.0839 & 0.0574 \\
\hline Lawyer per capita & -0.0376 & 0.6017 \\
\hline Growth rate of income & $-1.9152^{*}$ & 1.1194 \\
\hline State income deviation & $-0.1429 *$ & 0.0764 \\
\hline State and time dummies & yes & \\
\hline constant & $-2.1588^{* * *}$ & 0.4615 \\
\hline \multicolumn{3}{|c|}{ Financial benefit equation } \\
\hline \multicolumn{3}{|l|}{ Excluded adverse event variables } \\
\hline Health & $1.9230^{* * *}$ & 0.2287 \\
\hline Divorce & 0.3550 & 0.3391 \\
\hline unemployed & $-1.3573^{* * *}$ & 0.2645 \\
\hline Period of unemployment & $0.7437 * * *$ & 0.1970 \\
\hline Period of unemployment squared & $-0.0470 * * *$ & 0.0124 \\
\hline \multicolumn{3}{|l|}{ Other control variables } \\
\hline Age & $-0.1338^{* * *}$ & 0.0263 \\
\hline Age squared & $-0.00067^{* *}$ & 0.00028 \\
\hline Lagged bankruptcy filing rate & -3.7895 & 8.5598 \\
\hline Education & $-0.0306^{*}$ & 0.0169 \\
\hline Family size & $0.4164^{* * *}$ & 0.0401 \\
\hline Own business & $-3.2056^{* * *}$ & 0.2267 \\
\hline Own home & $-3.2106^{* * *}$ & 0.1331 \\
\hline Lawyer per capita & $-3.0452 *$ & 1.7055 \\
\hline Growth rate of income & -2.2850 & 3.4461 \\
\hline State income deviation & -0.2774 & 0.2114 \\
\hline State and time dummies & yes & \\
\hline Constant & 0.4705 & 1.4079 \\
\hline Standard deviation of error term & $3.2073^{* * *}$ & 0.0067 \\
\hline Log-likelihood & -61774.312 & \\
\hline
\end{tabular}


Table 4: Joint Determination Model (SCF data)

\begin{tabular}{|c|c|c|}
\hline variables & coefficient & std \\
\hline Correlation between the two & -0.2599 & 0.1746 \\
\hline \multicolumn{3}{|c|}{ Bankruptcy equation } \\
\hline Log financial benefit & $0.1462 * * *$ & 0.0400 \\
\hline Age & 0.0471 & 0.0307 \\
\hline Age squared & -0.00046 & 0.0003 \\
\hline Years of education & 0.2266 & 0.1579 \\
\hline Years of education squared & -0.0091 & 0.0061 \\
\hline Family size & $0.0544^{*}$ & 0.0331 \\
\hline Own business & -0.1998 & 0.1910 \\
\hline Own home & 0.0605 & 0.1340 \\
\hline Region dummies & Yes & \\
\hline constant & $-5.7178 * * *$ & 1.2966 \\
\hline \multicolumn{3}{|c|}{ Financial benefit equation } \\
\hline \multicolumn{3}{|l|}{ Excluded adverse variables } \\
\hline Health & 0.0161 & 1.0442 \\
\hline Divorce & $3.0169 * * *$ & 0.8821 \\
\hline unemployed & -0.3506 & 1.1332 \\
\hline Period of unemployment & 0.1937 & 0.1289 \\
\hline Period of unemployment squared & $-0.0046 *$ & 0.0024 \\
\hline \multicolumn{3}{|l|}{ Other control variables } \\
\hline Age & 0.0863 & 0.0848 \\
\hline Age squared & $-0.0033 * * *$ & 0.0009 \\
\hline Years of education & 0.6088 & 0.3863 \\
\hline Years of education squared & $-0.0519 * * *$ & 0.0158 \\
\hline Family size & 0.1311 & 0.1486 \\
\hline Own business & $-7.0680 * * *$ & 0.7049 \\
\hline Own home & $-5.1467 * * *$ & 0.4931 \\
\hline Region dummies & yes & \\
\hline Constant & 4.4593 & 3.2282 \\
\hline Standard deviation of error term & $3.0730 * * *$ & 0.0294 \\
\hline Log-likelihood & -4831.71 & \\
\hline
\end{tabular}


Table 5: Robustness Check with Different Combination of AE variables (PSID data)

\begin{tabular}{|c|c|c|c|}
\hline & (1) & (2) & (3) \\
\hline variables & divorce & health & unemployed \\
\hline Correlation between the two error & -0.157 & -0.1530 & -0.1288 \\
\hline \multicolumn{4}{|c|}{ Bankruptcy equation } \\
\hline Log financial benefit & $0.0826 * * *$ & $0.0816^{* * *}$ & $0.0758 * *$ \\
\hline Age & 0.0148 & 0.0148 & 0.0144 \\
\hline Age squared & $-0.0003^{* *}$ & $-0.0003^{* *}$ & $-0.0003^{* *}$ \\
\hline Lagged bankruptcy filing rate & $5.8535^{* *}$ & $5.8598 * *$ & $5.8147 * *$ \\
\hline Education & $-0.0205^{* *}$ & $-0.0203^{* *}$ & $-0.0204 * *$ \\
\hline Family size & 0.0219 & 0.0220 & 0.0226 \\
\hline Own business & 0.0554 & 0.0551 & 0.0512 \\
\hline Own home & -0.0806 & -0.0815 & -0.0855 \\
\hline Lawyer per capita & -0.0377 & -0.0395 & -0.0377 \\
\hline Growth rate of income & $-1.9044 *$ & $-1.9073 *$ & $-1.9136 *$ \\
\hline State income deviation & $-0.1410 *$ & $-0.1413^{*}$ & $-0.1434 *$ \\
\hline State and time dummies & yes & yes & yes \\
\hline constant & $-2.1774 * * *$ & $-2.1749 * * *$ & $-2.1470 * * *$ \\
\hline \multicolumn{4}{|c|}{ Financial benefit equation } \\
\hline \multicolumn{4}{|l|}{ Excluded adverse event variables } \\
\hline Health & & $1.9552^{* * *}$ & \\
\hline Divorce & 0.2930 & & \\
\hline unemployed & & & $-1.3401 * * *$ \\
\hline Period of unemployment & & & $0.7541^{* * *}$ \\
\hline Period of unemployment squared & & & $-0.0475 * * *$ \\
\hline \multicolumn{4}{|l|}{ Other control variables } \\
\hline Age & $-0.1308 * * *$ & $-0.1309 * * *$ & $-0.1321 * * *$ \\
\hline Age squared & $-0.0006 * *$ & $-0.0007 * *$ & $0.0006 * *$ \\
\hline Lagged bankruptcy filing rate & -0.5250 & 1.1547 & 3.5714 \\
\hline Education & $-0.0400 * * *$ & $-0.0290 *$ & $-0.0414^{* *}$ \\
\hline Family size & $0.4238^{* * *}$ & $0.4124 * * *$ & $0.4259 * * *$ \\
\hline Own business & $-3.2845^{* * *}$ & $-3.2436 * * *$ & $-3.2456 * * *$ \\
\hline Own home & $-3.1842 * * *$ & $-3.1468 * * *$ & $-3.2498^{* * *}$ \\
\hline Lawyer per capita & $-2.9152^{*}$ & $-3.0434 *$ & $-2.9500 *$ \\
\hline Growth rate of income & -0.9614 & -0.9563 & -2.3346 \\
\hline State income deviation & -0.2875 & -0.2829 & -0.2861 \\
\hline State and time dummies & yes & yes & yes \\
\hline Constant & $2.8076^{* *}$ & $2.7932 * *$ & 0.4481 \\
\hline Standard deviation of error term & $3.2099 * * *$ & $3.2084 * * *$ & $3.2089 * * *$ \\
\hline Log-likelihood & -62371.5 & -62335.8 & -61809.4 \\
\hline
\end{tabular}


Table 6: Robustness Check with Different Combination of AE variables (SCF data)

\begin{tabular}{|c|c|c|c|}
\hline & (1) & (2) & (3) \\
\hline variables & divorce & unemployed & health \\
\hline Correlation between the two & -0.2532 & -0.0406 & -0.0074 \\
\hline$\theta$ & \multicolumn{3}{|c|}{ Bankruptcy equation } \\
\hline Log financial benefit & $0.1447^{* * *}$ & $0.0982 *$ & 0.0911 \\
\hline Age & 0.0471 & 0.0444 & 0.0440 \\
\hline Age squared & -0.0005 & -0.0005 & -0.0005 \\
\hline Years of education & 0.2274 & 0.2446 & 0.2467 \\
\hline Years of education squared & -0.0092 & -0.0101 & $-0.0103^{*}$ \\
\hline Family size & 0.0544 & $0.0591 *$ & $0.0597^{*}$ \\
\hline Own business & -0.2017 & -0.2683 & -0.2806 \\
\hline Own home & 0.0583 & 0.0054 & -0.0040 \\
\hline Region dummies & Yes & Yes & Yes \\
\hline constant & $-5.7157 * * *$ & $-5.4954^{* * *}$ & $-5.4508 * * *$ \\
\hline \multicolumn{4}{|c|}{ Financial benefit equation } \\
\hline \multicolumn{4}{|l|}{ Excluded adverse variables } \\
\hline Health & & & -0.0785 \\
\hline Divorce & $3.0112^{* * *}$ & & \\
\hline unemployed & & -0.3793 & \\
\hline Period of unemployment & & 0.1946 & \\
\hline Period of unemployment squared & & $-0.0047^{*}$ & \\
\hline \multicolumn{4}{|l|}{ Other control variables } \\
\hline Age & 0.0751 & 0.1040 & 0.0929 \\
\hline Age squared & $-0.0032 * * *$ & $-0.0036^{* * *}$ & $-0.0035^{* * *}$ \\
\hline Years of education & 0.5873 & $0.6339 *$ & 0.6118 \\
\hline Years of education squared & $-0.0509 * * *$ & $-0.0534^{* * *}$ & $-0.0524^{* * *}$ \\
\hline Family size & 0.1359 & 0.1039 & 0.1083 \\
\hline Own business & $-7.0173^{* * *}$ & $-7.1141 * * *$ & $-7.0613^{* * *}$ \\
\hline Own home & $-5.1526 * * *$ & $-5.2125^{* * *}$ & $-5.2192^{* * *}$ \\
\hline Region dummies & yes & yes & yes \\
\hline Constant & 4.9251 & 4.2912 & 4.7577 \\
\hline Standard deviation of error term & $3.0757^{* * *}$ & $3.0769 * * *$ & $3.0795 * * *$ \\
\hline Log-likelihood & -4835.32 & -4836.33 & -4839.87 \\
\hline
\end{tabular}


Table 7: PSID Predictions

\begin{tabular}{|c|c|c|c|}
\hline $\begin{array}{l}\text { Hypothesized variable } \\
\text { change }\end{array}$ & $\begin{array}{l}\text { Mean effect on log } \\
\text { financial benefit(std) }\end{array}$ & $\begin{array}{c}\text { Percentage point } \\
\text { marginal effect(std) }\end{array}$ & $\begin{array}{l}\text { Percentage change in } \\
\text { the filing rate }\end{array}$ \\
\hline Financial benefit $+\$ 1000$ & --- & $\begin{array}{c}0.216 \\
(0.0007)\end{array}$ & 71.59 \\
\hline $\begin{array}{l}\text { Age of household head }+10 \\
\text { years }\end{array}$ & -0.0433 & $\begin{array}{c}-0.053 \\
(3.87 e-5)\end{array}$ & -18 \\
\hline Education +1 year & -0.0010 & $\begin{array}{c}-0.014 \\
(7.2 \mathrm{e}-6)\end{array}$ & -4.7 \\
\hline Family size +1 & 0.0156 & $\begin{array}{c}0.018 \\
(1.65 e-4)\end{array}$ & 6 \\
\hline Own home from 0 to 1 & -0.0997 & $\begin{array}{c}-0.071 \\
(0.0036)\end{array}$ & -24 \\
\hline unemployed (from 1 to 0 ) & 0.0372 & $\begin{array}{c}0.004 \\
(3.1 \mathrm{e}-5)\end{array}$ & 1.3 \\
\hline $\begin{array}{l}\text { Period of unemployment }-1 \\
\text { week }\end{array}$ & -0.0051 & $\begin{array}{c}-0.007 \\
(3.1 \mathrm{e}-6)\end{array}$ & -0.23 \\
\hline $\begin{array}{l}\text { health problem } \\
\text { (from } 1 \text { to } 0 \text { ) }\end{array}$ & -0.0937 & $\begin{array}{c}-0.011 \\
(1.2 \mathrm{e}-4)\end{array}$ & -3.7 \\
\hline divorce (from 1 to 0 ) & -0.0130 & $\begin{array}{c}-0.0015 \\
(2.97 e-6)\end{array}$ & -0.5 \\
\hline
\end{tabular}

Note: We compute each household's estimated probability of bankruptcy under the hypothesized change, holding all other household characteristics at their mean. The marginal effect is the change in the probability of bankruptcy for that household. The last column translates the marginal effects into the corresponding percentage change in the filing rate, as follows: divide the marginal effect by the filing probability, which is 0.3017 percent in the sample. Figures in parentheses are standard errors, computed using delta method. 
Table 8: SCF Predictions

\begin{tabular}{|c|c|c|c|}
\hline $\begin{array}{l}\text { Hypothesized variable } \\
\text { change }\end{array}$ & $\begin{array}{l}\text { Mean effect on log } \\
\text { financial benefit(std) }\end{array}$ & $\begin{array}{c}\text { Percentage point } \\
\text { marginal effect(std) }\end{array}$ & $\begin{array}{l}\text { Percentage change in } \\
\text { the filing rate }\end{array}$ \\
\hline Financial benefit $+\$ 1000$ & --- & $\begin{array}{c}0.56 \\
(0.0006)\end{array}$ & 43.75 \\
\hline $\begin{array}{l}\text { Age of household head }+10 \\
\text { years }\end{array}$ & -0.0102 & $\begin{array}{c}-0.06 \\
(4.9 e-4)\end{array}$ & -4.7 \\
\hline Education +1 year & -0.1041 & $\begin{array}{c}-0.08 \\
(0.0063)\end{array}$ & -6.25 \\
\hline Family size +1 & 0.0177 & $\begin{array}{c}0.10 \\
(5.37 e-4)\end{array}$ & 7.8 \\
\hline Own home from 0 to 1 & -0.0079 & $\begin{array}{c}-0.0038 \\
(9.89 e-4)\end{array}$ & -0.3 \\
\hline unemployed (from 1 to 0 ) & 0.0749 & $\begin{array}{c}0.045 \\
(2.67 e-4)\end{array}$ & 3.5 \\
\hline $\begin{array}{l}\text { Period of unemployment }-1 \\
\text { week }\end{array}$ & -0.0194 & $\begin{array}{c}-0.012 \\
(0.0017)\end{array}$ & -0.94 \\
\hline $\begin{array}{l}\text { health problem } \\
\text { (from } 1 \text { to } 0 \text { ) }\end{array}$ & -0.0733 & $\begin{array}{c}-0.046 \\
(2.43 e-4)\end{array}$ & -3.6 \\
\hline divorce (from 1 to 0 ) & -0.6065 & $\begin{array}{l}-0.44 \\
(0.015)\end{array}$ & -34.38 \\
\hline
\end{tabular}

We compute each household's estimated probability of bankruptcy under the hypothesized change, holding all other household characteristics at their mean. The marginal effect is the change in the probability of bankruptcy for that household. The last column translates the marginal effects into the corresponding percentage change in the filing rate, as follows: divide the marginal effect by the filing probability, which is 1.28 percent in the sample. Figures in parentheses are standard errors, computed using delta method. 


\section{References}

Adams, W., L. Einav, and J. Levin (2009): "Liquidity constraints and imperfect information in subprime lending," American Economic Review, 99(1), 49-84

Arabmazar, A. and P. Schmidt (1982): "An investigation of the robustness of the Tobit estimator to non-normality," Econometrica, 50, 1055-64.

Araujo, A. and M. Pascoa (2002): "Bankruptcy in a model of unsecured claims," Economic Theory, 20(3), 455-481.

Athreya, K. (2005): "Equilibrium Models of Personal Bankruptcy: A Survey," Federal Reserve Bank of Richmond Economic Quarterly, 91(2), 73-98.

Ausubel, L. M. (1991): "The failure of competition in the credit card market," American Economic Review," 81(1), 50-81.

Ausubel, L. M. (1997): “Credit card defaults, credit card profits, and bankruptcy," American Bankruptcy Law Journal, 71, 249-270.

Berkowitz, Jeremy, and Richard Hynes (1999): "Bankruptcy Exemptions and the Market for Mortgage Loans," Journal of Law and Economics, 42(2), 809-830

Crow, E. L., and K. E. Shimizu (1988): Lognormal Distributions: Theory and Applications, Dekker, New York.

Domowitz, lan, and Thomas L. Eovaldi (1993): "The Impact of the Bankruptcy Reform Act of 1978 on Consumer Bankruptcy," Journal of Law and Economics, 36(2), 803835

Domowitz, P. J. and R. L. Sartain (1999): “Determinants of the consumer bankruptcy decision," Journal of Finance, 54(1), 403-420.

Dubey, P., J. Geanakoplos, and M. Shubik (2005): “Default and punishment in general equilibrium," Econometrica, 73(1), 1-37.

Elias, S., A. Renauer, and R. Leonard (1999): How to file for chapter 7 bankruptcy, Nolo Press, 8th edition 
Eaton, J., and M. Gersovitz (1981): “Debt with Potential Repudiation: Theoretical and Empirical Analysis," Review of Economic Studies, 48(2), 289-309

Fan, W. and M. J. White (2003): "Personal bankruptcy and the level of entrepreneurial activity," Journal of Law and Economics, 46(2), 543-568.

Fay, S., E. Hurst, and M. J. White (2002): "The household bankruptcy decision," American Economic Review, 92(3), 706-718.

Gan, L., M. Hurd, and D. McFadden (2005): "Individual subjective survival curves," in D. Wise ed., Analyses of Economics of Aging, The University of Chicago Press, 2005: 377-411.

Gan, L. and T. Sabarwal (2005): “A Simple Test of Adverse Events and Strategic Timing Theories of Consumer Bankruptcy," NBER Working Paper Series, No. 11763, November

Gan, Li, Feng Huang, and Adalbet Mayer (2010). "A simple test of private information in the insurance markets with heterogeneous insurance demand." NBER Working Paper Series, No 16738.

Gan, L., and Roberto Mosquera (2008). “ An empirical study of the credit market with unobserved consumer types. “ NBER Working Paper Series, No 13873.

Geanakoplos, J., and W. Zame (2007): “Collateralized Asset Markets," mimeo.

General Accounting Office (1998): "Personal bankruptcy: the credit research center report on debtors' ability to pay," GAO/GGD-98-47.

General Accounting Office (1999): “Personal bankruptcy: a report on petitioner's ability to pay," GAO/GGD-99-103.

Gropp, Reint E., John Karl Scholz, and Michelle J. White. (1997): "Personal Bankruptcy and Credit Supply and Demand." Quarterly Journal of Economics 112:217-52.

Lefgren, Lars and Frank McIntyre (2009), "Explaining the Puzzle of Cross-State Differences in Bankruptcy Rates," Journal of Law and Economics, 52(2), 367-393

Li,Wenli, Michelle J. White, and Ning Zhu. (2011): "Did Bankruptcy Reform Cause Mortgage Defaults to Rise?" American Economic Journal: Economic Policy 3(4):123-47. 
Greenhalgh-Stanley, Nadia and Shawn Rohlin (2013): "How Does Bankruptcy Law Impact the Elderly's Business and Housing Decisions?" Journal of Law and Economics, 56(2), 417-451

Gross, T., M.J.Notowidigdo, and J. Wang (2012): "Liquidity Constraints and Consumer Bankruptcy: Evidence From Tax Rebates," NBER Working Paper Series, No. 17807

Gross and Souleles (2002):"Do Liquidity Constraints And Interest Rates Matter For Consumer Behavior? Evidence From Credit Card Data," The Quarterly Journal of Economics, 117(1), 149-185

Han, S. and G. Li (2009): "Household borrowing after personal bankruptcy," Working paper, Finance and Economics Discussion Series, 2009-17

Hoelle, M. (2009): “A Simple Model of Bankruptcy in General Equilibrium," Working paper, University of Pennsylvania

Kennickell, A., M. Starr-McCluer, and B. J. Surette (2000). "Recent change in U.S. family finances: results from the 1998 Survey of Consumer Finances." Federal Reserve Bulletin, Division of Research and Statistics, Federal Reserve Board

Livshits, I, J. Macgee, and M. Tertilt (2007): “Consumer bankruptcy: a fresh start," American Economic Review, 97(1), 402-418

Livshits, I, J. Macgee, and M. Tertilt (2010): "Accounting for the rise in consumer bankruptcies," American Economic Journal: Macroeconomics, 2(2): 165-93

Luckett, C. A. (2002): "Personal Bankruptcies," The Impact of Public Policy on Consumer Credit, 69-108

Mansi, Sattar A., William F. Maxwell, and John K. Wald (2009): "Creditor Protection Laws and the Cost of Debt," Journal of Law and Economics, 52(4), 701-717

Modica, M., A. Rustichini, and J. M. Tallon (1999): “Unawareness and bankruptcy: a general equilibrium model," Economic Theory, 12(2), 259-292.

Musto, D. K. (2004): "What happens when information leaves a market? Evidence from post bankruptcy consumers," Journal of Business, 77(4), 1-24

Powell, J. (1984): "Least absolute deviations estimation for the censored regression model," Journal of Econometrics, 25: 303-325. 
Sabarwal, T. (2003): "Competitive equilibria with incomplete markets and endogenous bankruptcy," Contributions to Theoretical Economics, 3(1), Art. 1.

Stanley, D. T., and M. Girth (1971): Bankruptcy: problem, process, reform. Brookings Institution, Washington DC

Sullivan, T. A., E. Warren, and J. L. Westbrook (1989): As we forgive our debtors. Oxford University Press

Sullivan, T. A., E. Warren, and J. L. Westbrook (1994): “Consumer debtors ten years later: a financial comparison of consumer bankrupts, 1981-1991," American Bankruptcy Law Journal, 68, 121-154.

Sullivan, T. A., E. Warren, and J. L. Westbrook (2000): The Fragile Middle Class. Yale University Press

Traczynski, J. (2011): "Divorce Rates and Bankruptcy Exemption Levels in the United States," Journal of Law and Economics 54(3), 751-779

Warren, C. (1935): Bankruptcy in United States history. Harvard University Press

White, M. J. (1987): “Personal bankruptcy under the 1978 bankruptcy code: an economic analysis," Indiana Law Journal, 63(1), 1-53.

White, M. J. (1998): “Why don't more households file for bankruptcy?” Journal of Law, Economics, and Organization, 14(2), 205-231.

Zame, W. (1993): "Efficiency and the role of default when security markets are incomplete," American Economic Review, 83(5), 1142-1164. 